\title{
IMPLEMENTASI STRATEGI ACTIVE LEARNING DALAM MENINGKATKAN PRESTASI BELAJAR SISWA PADA MATA PELAJARAN PENDIDIKAN AGAMA ISLAM DI SDIT BAITUL JANNAH BANDAR LAMPUNG
}

\author{
Rahmat Efendi, Moh. Masrur \\ Dosen STIKes Muhammadiyah Pringsewu \\ Dosen STIT Pringsewu \\ Email: abubassam82@gmail.com, masrurpring1000@gmail.com
}

\begin{abstract}
The aim of this research is to describe active learning strategy to increase the students' achievement at IV grade in Baitul Jannah SDIT and to describe the implementation of active learning strategy in islamic education lesson in Baitul Jannah SDIT. The kind of this research is quantitative research with data collective isusing observation, interview and documentation. And for data analyze is using qualitative descriptive, that is not in numbers but words form, sentence or paraghraph in descriptive form.

Based on the result of the research can be concluded that aplly of active learning strategy in learning process of islamic education lesson in Baitul Jannah SDIT had been run well. When in teaching learning process thathad been done in the clas, such as students are active to ask the question that they have not understand yet, active to do the task that had been given by the teacher. Between the methodes that had been used in islamic education lesson in Baitul Jannlah SDIT that direct to active learning strategy is asking and answering method, demonstration method, guided teaching, jigsaw learning, sane age tutor, memorize, role play, demonstration, quiz, and others. The implemtation of active learning strategy in teaching learning process of islamic education lesson in Baitul Jannah SDIT gives the good result for example their score in raport book, beside of their good score with active learning strategy the islamic education lesson that delivered in the class can apply in daily activities such as students love to read quran, pray 5 times, duhha sunnah pray, and other religious activites in islam.
\end{abstract}

\begin{abstract}
ABSTRAK
Adapun tujuan dari penelitian ini adalah untuk mendeskripsikan strategi active learning dalam meningkatkan prestasi belajar siswa kelas IV di SDIT Baitul Jannah, dan untuk mendeskripsikan implementasi strategi active learning pada mata pelajaran PAI di SDIT Baitul Jannah. Jenis penelitian ini adalah penelitian kualitatif dengan tehnik pengumpulan data melalui observasi, wawancara, dan dokumentasi. Adapun untuk anlisis data digunakan adalah analisis deskriptif kualitatif, yaitu analisis data bukan dengan angka-angka melainkan dalam bentuk kata-kata, kalimat atau paragraf yang dinyatakan dalam bentuk deskriptif.

Berdasarkan hasil analisis dapat disimpulkan bahwa penerapan strategi active learning dalam proses pembelajaran pendidikan agama Islam di SDIT Baitul Jannah sudah berjalan dengan baik. Hal tersebut terlihat pada saat proses belajar mengajar yang dilakukan didalam kelas, antara lain siswa aktif bertanya tentang pelajaran yang belum dimengerti,aktif mengerjakan tugas-tugas yang diberikan oleh guru. Diantara metode-metode yang digunakan dalam pembelajaran pendidikan agama Islam di SDIT Baitul Jannah yang mengarah kepada strategi active learning adalah metode tanya jawab, metode demonstrasi, guided teaching, jigsaw learning, tutor sebaya, hafalan, bermain peran, demonstrasi, quis, dan lain sebagainya. Implementasi strategi active learning dalam proses pembelajaran Pendidikan Agama Islam di SDIT Baitul Jannah membuahkan hasil yang diharapkan seperti yang terlihat pada hasil nilai rapor mereka. Selain hasil nilai rapor yang baik dengan strategi active learning menjadikan pelajaran Pendidikan Agama Islam yang disampaikan di dalam kelas dapat teraplikasikan juga dalam kehidupan sehari-hari, misal siswa menjadi gemar mengaji, melaksanakan sholat wajib, sholat sunnah dluha, dan ibadah-ibadah lain yang dianjurkan dalam agama Islam.
\end{abstract}

Kata Kunci: Pendidikan Agama Islam, Pembelajaran, Active Learning 


\section{A. PENDAHULUAN}

Proses pendidikan berfungsi sebagai alat untuk mencapai tujuan pendidikan, yakni kompetensi yang harus dicapai dalam ikhtiar pendidikan. Bagaimanapun bagus dan idealnya suatu rumusan kompetensi, pada akhirnya keberhasilan sangat tergantung kepada pelaksanaan proses pembelajaran yang dilakukan oleh guru (Sanjaya, 2008:6).

Berdasarkan peraturan pemerintah RI No.19 tahun 2005 tentang SNP pasal 19 ayat dinyatakan bahwa: (1) Proses pembelajaran pada satuan pendidikan diselenggarakan secara inspiratif, menyenangkan, menantang, memotivasi siswa untuk berpartisipasi aktif, serta memberikan ruang yang cukup bagi prakarsa, kreativitas, dan kemandirian sesuai dengan bakat, minat, dan perkembangan fisik serta psikologis siswa. (2) "Selain ketentuan sebagaimana dimaksud pada ayat (1), dalam proses pembelajaran pendidik memberikan keteladanan. (3) Setiap satuan pendidikan melakukan perencanaan proses pembelajaran, pelaksanaan proses pembelajaran, penilaian hasil pembelajaran, dan pengawasan proses pembelajaran untuk terlaksanakanya proses pembelajaran yang efektif dan efisien (Pendidikan, 2010: 17-18).

Dalam proses belajar mengajar, salah satu faktor yang sangat mendukung keberhasilan guru dalam melaksanakan pembelajaran adalah kemampuan guru dalam menguasai dan menerpakan metode pembelajaran (Susanto, 2016). Guru dituntut untuk menguasai macammacam metode pembelajaran yang sesuai dengan karakteristik materi dan siswa (Jihad, 2013).

Mengaktifkan belajar siswa dalam kegiatan pembelajaran merupakan salah satu cara menghidupkan dan melatih memori siswa agar bekerja dan berkembang secara optimal (Susilana dkk., 2008). Guru harus memberi kesempatan kepada siswa untuk mengoptimalkan memorinya bekerja secara maksimal dengan bahasanya dan melakukan dengan kreativitasnya sendiri (Rosalin, E., 2008). Jadi siswa tidak hanya diam mendengarkan materi dari guru dengan metode ceramah saja. Metode mengajar merupakan salah satu cara-cara yang dipergunakan guru dalam mengadakan hubungan siswa pada saat berlangsungnya pengajaran. Oleh karena itu, peranan metode mengajar adalah sebagai alat untuk menciptakan proses belajar mengajar (Yamin, 2013).

Keaktifan siswa di kelas sangat diperlukan karena proses kerja sistem memori sangat membantu perkembangan emosional siswa (Silberman, 2009. Dalam Islam, penekanan proses kerja sistem memori terhadap signifikansi fungsi kognitif (aspek aqidah) dan fungsi sensori (indera-indera) sebagai alat-alat penting untuk belajar sangat jelas (Arief, 2002).

Dengan metode aktif, siswa akan mampu memecahkan masalahnya sendiri dalam proses belajar (Ismail, 2008). Maka untuk mengaktifkan siswa agar secara sukarela tumbuh kesadaran mau dan senang belajar, guru harus mempunyai strategi yang baik supaya pendidikan dan pengajaran yang disampaikan memperoleh respons positif, menarik perhatian dapat dikembangkan dan terimplementasi dalam sikap yang positif pula (Arifin, 2009).

SDIT Baitul Jannah adalah sekolah yang bercirikan khas Islam di bawah naungan DIKNAS yang diintegrasikan dengan kurikulum lokal yang menitikberatkan kepada pendidikan agama Islam.

Dalam proses pembelajaran di SDIT Baitul Jannah saat ini telah banyak menggunakan berbagai macam metode untuk mengaktifkan pembelajaran di dalam kelas khususnya pada mata pelajaran Pendidikan Agama Islam. Sehingga prestasi belajar siswa terutama pada mata pelajaran PAI cukup memuaskan, salah satu metode yang digunakan adalah Active Learning.

\section{B. TUJUAN PENELITIAN}

Tujuan dari penelitian ini adalah untuk mendeskripsikan strategi active learning dalam meningkatkan prestasi belajar siswa kelas IV di SDIT Baitul Jannah, dan untuk mendeskripsikan implementasi strategi active learning pada mata pelajaran PAI di SDIT Baitul Jannah

\section{METODE PENELITIAN}

\section{Jenis Penelitian}

Penelitian ini menggunakan pendekatan deskriptif kualitatif. Pendekatan ini merupakan suatu proses pengumpulan data secara sistematis dan intensif untuk memperoleh pengetahuan tentang implementasi strategi active learning dalam meningkatkan prestasi belajar siswa pada mata pelajaran pendidikan agama Islam di SDIT Baitul Jannah Bandar Lampung.

Menurut Bogdan dan Taylor, menyatakan bahwa "Metode kualitatif sebagai prosedur penelitian yang menghasilkan data-data deskriptif yang berupa kata-kata tertulis atau lisan dari orang-orang dan prilaku yang diamati”. Kemudian lebih lanjut, menyatakan bahwa:

Penelitian kualitaif berakar pada akar alamiah sebagai keutuhan, mengandalkan manusia sebagai alat penelitian, memanfaatkan metode kualitatif, mengadakan anlisis data secara induktif, mengarahkan sasaran penelitiannya pada usaha menemukan teori dari dasar, bersifat deskriptif, lebih mementingkan proses dari pada hasil, membatasi studi dengan fokus, memiliki seperangkat kriteria untuk memeriksa keabsahan data, rancangan penelitiannya bersifat sementara, 
dan hasil penelitiannya disepakati oleh kedua belah pihak, yakni peneliti dan subjek peneliti.

Berdasarkan pendapat di atas, maka penelitian ini diarahkan pada proses belajar mengajar dikelas khususnya dalam kaitannya dengan strategi guru untuk mengaktifkan siswa dalam proses pembelajaran pendidikan agama Islam di dalam kelas dengan menggunakan strategi active learning.

\section{Sumber Data}

Yang dimaksud dengan sumber data dalam penelitian adalah subjek dari mana data dapat diperoleh.Adapun sumber data yang diambil oleh penulis dalam penelitian ini adalah sumber data utama yang berupa kata-kata dan tindakan, serta sumber data tambahan yang berupa dokumendokumen.

Sebagaimana yang telah diungkapkan oleh Moleong bahwa: "Sumber dan jenis data terdiri dari kata dan tindakan, sumber data tertulis, foto dan data statistik". Sehingga beberapa sumber data yang dimanfaatkan dalam penelitian ini meliputi:

a. Informan penelitian, yaitu orang yang dimanfaatkan untuk memberikan Informasi tentang situasi dan kondisi latar penelitian. Adapun orang-orang yang dapat membantu memberikan keterangan yang dibutuhkan oleh peneliti yaitu yang mengerti betul akan implementasi strategi active learning pada mata pelajaran pendidikan agama Islam di SDIT Baitul Jannah Bandar Lampung. Para informan-informan tersebut meliputi:

1) Kepala SDIT Baitul Jannah Bandar Lampung (melalui wawancara)

2) Waka kurikulum SDIT Baitul Jannah Bandar Lampung (melalui wawancara)

3) Guru agama SDIT Baitul Jannah Bandar Lampung (melalui wawancara)

4) Siswa kelas IVSDIT Baitul Jannah Bandar Lampung (melalui wawancara).

Sebagaimana yang telah diungkapkan oleh Moleong bahwa:

Kata-kata dan tindakan orang-orang yang diamati atau diwawancarai merupakan sumber data utama. Sumber data utama dicatat melalui catatan tertulis dan melalui perekaman video/audio tapes, pengambilan foto atau film, pencatatan sumber data utama melalui wawancara atau pengamatan berperan serta sehingga merupakan hasil usaha gabungan dari kegiatan melihat, mendengar dan bertanya.

Maka sumber data utama yang menjadi informan kunci (key informan) dalam penelitian ini adalah: Guru agama, beliaulah yang memberikan pengarahan kepada peneliti dalam pengambilan sumber data, dan memberi rekomendasi kepada informan lainnya seperti: Kepala Sekolah, dan Kepala Sekolah juga memberikan rekomendasi kepada informan lainnya. Sehingga semua data-data yang diperlukan oleh peneliti terkumpul, sesuai dengan kebutuhan penelitian b. Lokasi penelitian, yaitu tempat atau denah lokasi berlangsungnya penelitian dilakukan. Dalam penelitian ini sengaja mengambil lokasi penelitian di SDIT Baitul Jannah Bandar Lampung karena, mengingat penelitian yang akan dilakukan mengenai implementasi strategi active learning pada bidang studi PAI dan itu sudah di aplikasikan di SDIT Baitul Jannah Bandar Lampung.

\section{Teknik Pengumpulan Data}

Pengumpulan data merupakan proses pengadaan data untuk keperluan suatu penelitian yang merupakan langkah penting dalam metode ilmiah. Oleh karena itu pengumpulan data mutlak diperlukan dalam suatu penelitian. Teknik pengumpulan data yang digunakan penulis dalam penelitian ini meliputi:

a. Observasi, yaitu pengamatan dan pencatatan yang sistematis terhadap gejala-gejala yang diteliti. Observasi ini dilakukan untuk mengamati keadaan pada proses kegiatan belajar mengajar di kelas terkait dengan pengamatan pembelajaran kooperatif.

b. Wawancara,yaitutanya jawab lisan antara dua orang atau lebihsecara langsung. Pada penelitian ini penulis mengadakan wawancara denganguru dan empat orang siswa guna mendapatkan informasi secaralangsung.

c. Dokumentasi, yaitupengambilan data yang diperoleh melalui dokumen-dokumen.

\section{Teknik Analisis Data}

Analisis data dimulai dengan pengolahan data mentah.Mengolah data berarti membuat data ringkasan berdasarkan data mentah hasil pengumpulan data.

Analisis data kualitatif adalah upaya yang dilakukan dengan jalan bekerja dengan data, mengorganisasikan data, memilah-milahnya menjadi satuan yang dapat dikelola, mensintesiskannya, mencari dan menemukan pola, menemukan apa yang penting dan apa yang dipelajari, dan memutuskan apa yang dapat diceritakan kepada orang lain (Moleong, 2009: 248).

Menurut Seiidel yang dikutip oleh Lexy J. Moleong, analisis data kualitatif proses berjalannya sebagai berikut:

a. Mencatat yang menghasilkan catatan lapangan, dengan hal itu diberi kode agar sumber datanya tetap dapat ditelusur.

b. Mengumpulkan, memilah-milah, mengklarifikasikan, mensintensiskan, membuat ikhtisar, dan membuat indeksnya.

c. Berpikir dengan jalan membuat agar kategori data itu mempunyai makna, mencari dan menemukan pola dan hubungan-hubungan, dan membuat temuan-temuan umum.

Pada penelitian kualitatif, analisis data dimulai dari reduksi data, kategorisasi data, sintesis dan diakhiri dengan menyusun hipotesis kerja.Analisis data dalam penelitian kualitatif dilakukan sejak 
sebelum memasuki lapangan, selama dilapangan dan setelah selesai penelitian.

\section{HASIL PENELITIAN}

\section{Implementasi Strategi Active Learning dalam Pembelajaran Pendidikan Agama Islam di SDIT Baitul Jannah Bandar Lampung. \\ Berdasarkan hasil observasi terhadap guru} yang memegang materi pelajaran PAI, proses pembelajaran berlangsung di dalam kelas dengan menggunakan strategi active learning, guru tersebut mengajar pada kelas IV, beliau adalah guru tetap disana. Beliau dalam menyampaikan materi pelajaran PAI ada beberapa tahapan/langkah-langkah yang harus dilakukan untuk menerapkan strategi active learning, yaitu sebagai berikut:

a. Perencanaan penerapan strategi active learning pada mata pelajaran Pendidikan Agama Islam

Perencanaan adalah tahap awal yang harus dilalui guru dalam setiap proses pembelajaran. Guru harus mempersiapkan segala sesuatunya agar proses pembelajaran yang dilaksanakan berjalan dengan dengan baik, efektif, dan efesien. Baik dari segi tujuan pembelajaran yang tersedia, strategi dan metode yang digunakan maupun waktu yang tersedia, semua itu dibuat dalam perencanaan tertulis seperti: Silabus, program tahunan, program semesteran, dan skenario pembelajaran/RPP.

Berdasarkan data yang diperoleh melalui observasi dapat diketahui bahwa sebelum mengawali kegiatan pembelajaran guru tersebut mempunyai persiapan yang cukup matang seperti buku PAI, LKS, spidol, tajwid, alquran, DVD dan kertas serta Rencana Persiapan Pembelajaran.

b. Pelaksanaan penerapan strategi active learning pada mata pelajaran Pendidikan Agama Islam

Pelaksanaan kegiatan pembelajaran pada dasarnya merupakan pelaksanaan dari perencanaan yang telah disusun sebelumnya. Dalam pelaksanaan itu menunjukkan penerapan langkahlangkah suatu strategi pembelajaran yang ditempuh untuk menyediakan pengalaman belajar yang berpusat pada siswa dan dalam proses itu dapat dilihat bagaimana teknik guru menerapkan strategi pembelajaran yang menuntut adanya keaktifan para siswa dengan metode media, dan strategi yang tepat dalam menyajikan materi pelajaran sehingga tujuan dari pembelajaran dapat tercapai dengan baik.

Dalam mengembangkan proses pembelajaran PAI, guru tersebut mengajar di kelas IV, memilih strategi pembelajaran dan metode yang sesuai dengan kompetensi apa yang ingin dicapai. Dari setiap kompetensi juga mengharuskan siswa untuk memahami dan menguasai tiap-tiap indikator materi yang dipelajari.Menurut guru tersebut, pemilihan strategi pembelajaran didasarkan pada isi materi yang dipelajari dan alokasi waktu yang tersedia untuk mendalami materi tersebut.
Sesuai hasil observasi yang dilaksanakan, penulis dapat mengetahui bahwa pemilihan strategi active learning yang dilakukan guru PAI tersebut dapat mereka terapkan sesuai dengan langkahlangkah yang telah menjadi ketentuan.Namun waktu yang tersedia terkadang kurang cukup, sebab kendalanya adalah siswa yang terkadang kurang tanggap dan kurang perhatian terhadap materi dan strategi yang di gunakan dalam pembelajaran PAI.

Adapun Langkah-langkah yang digunakan dalam menerapkan strategi active learning Card sort pada mata pelajaran PAI dengan materi Q.S Al-Ikhlas adalah sebagai berikut:

a. Kegiatan Awal

1) Guru mengucapkan salam dan berdoa

2) Mengkondisikan kelas

3) Menyampaikan kompetensi dasar yang akan dicapai

4) Melaksanakan pretest dan appersepsi

b. Kegiatan inti

1) Guru menyampaikan materi yang akan dipelajari yaitu Q.S Al-Ikhlas.

2) Siswa bersama-sama membaca surah AlIkhlas

3) Siswa dibagi menjadi empat kelompok

4) Masing-masing kelompok diberi satu set kartu yang berisi potongan-potongan ayat yang sudah diacak sehingga kategori yang mereka sortir tidak tampak

5) Setiap kelompok diminta mensortir kartukartu tersebut termasuk ke dalam kelompok ayat keberapa dari surah Al-Ikhlas

6) Kemudian siswa diminta menempelkan kartu pada karton yang sudah ditempel di papan tulis

7) Setelah selesai guru bersama-sama siswa memeriksa hasil dari hasil pensortiran kartu

8) Kemudian setiap kelompok berdiskusi menterjemahkan ayat-ayat Surah Al-Iklas

9) Apabila selesai hasilnya ditempelkan dipapan tulis

10)Diakhir pelajaran untuk mengetahui sampai sejauh mana pemnahaman siswa terhadap materi yang telah dipelajari, maka dilaksanakan strategi giving question and getting answer

11) Setiap siswa diberi 2 potong kertas dan diminta untuk melengkapi pertanyaan; kertas 1 berisi saya masih belum paham tentang... dan kertas ke 2 berisi saya dapat menjelaskan tentang...

12) Setelah selesai kumpulkan dengan teman sekelompoknya.

13)Masing-masing kelompok memilih pertanyaan yang ada(kartu1) dan juga topik yang dapat mereka jelaskan (kertas 2)

14)Minta setiap kelompok membacakan pertanyaan yang mereka seleksi. Jika ada diantara siswa yang dapat menjawab, maka diberi kesempatan untuk menjawab, bila tidak maka guru yang menjawab 
15)Minta setiap kelompok untuk menyampaikan apa yang dapat mereka jelaskan dari kertas 2

c. Kegiatan Akhir

1) Guru menyimpulkan pelajaran yang telah dipelajari

2) Guru mengajukan pertanyaan ulang seputar materi pelajaran yang telah dipelajari

3) Memberikan penugasan

4) Evaluasi penerapan strategi active learning pada mata pelajaran Pendidikan Agama Islam

Implementasi strategi active learning dalam pembelajaran Pendidikan Agama Islam di SDIT Baitul Jannah sudah berjalan dengan baik. Hal ini dapat dilihat dari segi proses kegiatan pembelajaran Pendidikan Agama Islam, keaktifan guru dan siswa, hasil belajar siswa, dan dari segi metode yang digunakan dalam pembelajaran pendidikan agama Islam.

\section{Prestasi Belajar Siswa SDIT Baitul Jannah Setelah di Terapkan Strategi Active Learning}

Ciri-ciri suatu kegiatan bisa disebut belajar apabila kegiatan tersebut menghasilkan perubahan pada diri seseorang berupa perubahan terjadi secara sadar, bersifat fungsional, bersifat positif aktif, bukan bersifat sementara, mencakup seluruh tingkah laku, dan bertujuan atau terarah.Penerapan PAKEM dalam pembelajaran pendidikan agama Islam di SDIT Baitul Jannah sudah berjalan dengan baik.Dalam hal ini dapat dilihat dari segi metode yang digunakan dalam pembelajaran pendidikan agama Islam, dari kegiatan belajar mengajar, upaya guru dalam menciptakan metode belajar baru dan hasil belajar siswa. Sejalan dengan tujuan belajar untuk memperoleh hasil belajar yang pada prinsipnya ada perubahan antara keadaan sebelum dan sesudah belajar, yang semula tidak tahu menjadi tahu, yang semula tidak bisa menjadi bisa dan yang semula berprestasi buruk menjadi baik

Hasil wawancara dengan guru PAI dan daftar nilai siswa di atas menunjukkan bahwa pembelajaran PAI menggunakan strategi active learning berpengaruh pada nilai hasil akhir siswa

Dari uraian di atas yang menjelasankan tentang poses belajar mengajar dengan menggunakan metode tradisional, metode qusi dapat diambil kesimpulan bahwasanya minat dan curah perhatian siswa yang penuh maka akan mempengaruhi prestasi belajar secara maksimal, begitu pula dengan sebaliknya surutnya minat dan curah perhatian siswa maka akan mempengaruhi prestasi belajar, sehingga menjadi di bawah rata-rata yang semestinya. Semua hasil belajar tiap anak tentulah tidak sama antara yang satu dengan yang lainnya, ada yang tinggi, sedang dan ada yang rendah prestasi belajar yang dicapai antara yang satu dengan yang lainnya tentu tidak sama, karena kemampuan dan kesempatan setiap orang adalah berbeda.
Dari beberapa penjelasan di atas, maka dapat disimpulkan bahwa implementasi strategiactive learning di SDIT Baitul Jannah sudah berjalan dengan baik. Hal ini dapat dilihat dari segi metode yang digunakan dalam pembelajaran pendidikan agama Islam, dari segi proses kegiatan pembelajaran pendidikan agama Islam, keaktifan guru dan siswa dalam kegiatan belajar mengajar sehingga hasilnya sungguh memuaskan. Semuanya terbukti pada nilai hasil rapor MID mereka dan juga nilai pembelajaran sehari-harinya.

\section{E. KESIMPULAN}

Berdasarkan uraian hasil dari penelitian yang penulis tuangkan pada setiap bab-bab sebelumnya, maka dapat diambil beberapa kesimpulan sebagai berikut:

1. Dalam melaksanakan kegiatan belajar mengajar pendidikan agama Islam di SDit Baitul Jannah, guru menerapkan strategi active learning yang terdiri dari metode guided teaching, jigsaw learning, tutor sebaya, hafalan, bermain peran, demonstrasi, quis, dan lain sebagainya. Dalam penerapan metode-metode tersebut, guru menyesuaikan dengan jenis maupun sifat bahan materi pelajaran dengan situasi dan kondisi dalam proses belajar mengajar. Cara penerapan strategi active learning dalam pembelajaran pendidikan agama Islam di SDIT Baitul Jannah dalam menggerakkan siswa agar aktif belajar, diperlukan keterlibatan secara terpadu, seimbang, dan berkesinambungan antara media, metode, $\mathrm{g}$ uru dan siswa. Diantara cara-cara tersebut adalah mengarahkan kepada jenis interaksi belajar yang optimal, menuntut bebagai jenis aktifitas siswa, sumber belajar mengajar yang sesuai dengan tujuan yang hendak dicapai, menggunakan metode, menggunakan media yang bervariasi, mengarahkan kepada sumber belajar. Dan juga guru-guru di SDIT Baitul Jannah dalam usaha mengefektifkan metode-metode yang diterapkan dalam kegiatan belajar mengajar, maka berupaya membuat program mingguan presentasi guru mengenai penciptaan 1 (satu) metode baru secara bergilir, supaya tidak kehabisan akal dalam menciptakan suasana belajar yang tidak membosankan. Dari keterangan ini terlihat jelas bahwasanya memang di SDIT Baitul Jannah benar-benar berupaya keras dalam implementasi strategi active learning dalam pembelajaran dikelas.

2. Implementasi strategi active learning di SDIT Baitul Jannah dampak yang positif diantaranya adalah siswa menjadi termotivasi untuk meningkatkan prestasi belajar dan kadar keaktifan siswa dalam proses belajar mengajar PAI menjadi meningkat, dan nilai hasil dari pembelajaran tersebut semakin baik. Berdasarkan hasil observasi kelas yang dilakukan guru dengan perbandingan penggunaan metode belajar tradisional dan metode quis. Hanya dengan cara pemilihan penyampaian materi yang berbeda dapat 
memengaruhi prestasi yang dicapai siswa. Ketika guru mencoba memakai metode tradisional dalam penyampaian materi pelajaran, hasil prestasi siswa menjadi surut dengan nilai kebanyakan dibawah rata-rata semua. Akan tetapi ketika guru menggunakan metode quis dalam penyampaian materi, prestasi siswa menjadi maksimal dan di atas rata-rata semuanya. Selain itu juga dapat terbuktikan pada hasil nilai MID Semester Ganjil dan nilai harian para siswa yang mayoritas di atas rata-rata, karena selama ini di SDIT Baitul Jannah menggunakan strategi active learning dalam penyampaian materi pelajaran

\section{DAFTAR PUSTAKA}

Wina Sanjaya, Setrategi Pembelajaran Berorientasi Standar Proses Pendidikan, Jakarta: Kencana, 2008

\section{--------------, Perencanaan dan Desain Sistem} Pembelajaran, Jakarta: Kencana, 2008

Standar Nasional Pendidikan Beserta Delapan Peraturan-Peraturan Menteri Pendidikan Nasional Tentang Standar Isi, Standar Kompetensi Lulusan, Standar Pengelolaan Pendidikan, Standar Pendidik dan Tenaga Kependidikan, Standar Sarana dan Prasarana, Standar

Muhaimin, Paradigma Pendidikan Islam Upaya Mengaktifkan Pendidikan Agama Islam di Sekolah Bandung: Remaja Rosdikarya, 2001

Mel Silberman, Active Learning 101 Cara Strategi Pembelajaran Aktif, Yogyakarta: Yappendis, 2009

Martinis Yamin, Strategi, Metode dalam Model Pembelajaran, Jakarta: GP Press Group, 2013

Muzayyin Arifin, Filsafat Pendidikan Islam, Jakarta: Bumi Aksara, 2009

Armai Arief, Reformulasi Pendidikan Islam, Jakarta: CRSD PRESS, 2005

Standar Isi Pendidikan Agama Islam Sekolah Menengah Pertama (SMP), PERMENDIKNAS NO. 22 TAHUN 2006

Ismail SM, Strategi Pembelajaran Agama Islam Berbasis PAIKEM: Pembelajaran Aktif, Inovatif, Kreatif, Efektif danMenyenangkan Semarang: RaSAIL Media Group, 2008

Moleong, Lexy. Metode Penelitian Kualitatif. Bandun g IKIP: CV Remaja Karya. 2002

Ahmad Susanto, M. P. (2016). Teori belajar dan pembelajaran di sekolah dasar. Kencana.

Jihad, A. (2013). Menjadi guru profesional: Strategi meningkatkan kualifikasi dan kualitas guru di era global. Penerbit Erlangga.

Susilana, R., Si, M., \& Riyana, C. (2008). Media Pembelajaran: Hakikat, Pengembangan, Pemanfaatan, dan Penilaian. CV. Wacana Prima.

Rosalin, E. (2008). Guru dalam meningkatkan daya pikir siswa. JURNAL MANAJEMEN PENDIDIKAN, 8(2). 